\title{
四重極質量分析計及び電離真空計に拈ける 水素同位体の相対感度*
}

\author{
三宅 均**.松山 政夫**.渡辺 国昭**
}

（昭和62年 1 月 9 日 受理)

Determination of the Relative Sensitivities of a Quadrupole Mass

Spectrometer and Ionization Gauge for Hydrogen Isotopes

\author{
Hitoshi MIYAKE**, Masao MATSUYAMA** and Kuniaki WATANABE** \\ (Tritium Research Center, Toyama University, 3190 Gofuku, Toyama 930, Japan)
}

(Received January 9, 1987)

\section{1.はじめに}

近年トリチウム取扱い技術の進歩に伴ない, 従来の放 射能カウンティング法では計測できないような多量のト リチウムが使用されるようになってきている．このため 従来のカウンティング法に代るトリチウム計測法の確立 が望まれている。また，重水素とトリチウムを用いる核 融合反応実験装置においては, 通常の真空計測とともに トリチウムの圧力あるいは流量を正確に測定する必要が ある・

高真空圧領域でのトリチウムの計測には様々な真空計 及び分圧計が用いられるが，電離真空計及び四重極質量 分析計の利用が一般的である1,2). 但し，これらの全圧 計及び分圧計は気体の種類によって感度が異なるので事 前に何らかの方法でトリチウムに対する感度を求めてお く必要がある. 電離真空計及び質量分析計の絶対感度は それらの幾何学的構造のみならず操作条件により著しく 異なるが，相対感度は，例えば電離真空計においては， それらの影響をあまり受けないことが知られている3〜6). 同様な現象は質量分析計に拈いても期待できる．従っ て，ある種の適当な気体，例えば窒素，に対する感度と 対象とする気体の相対感度がわかれば，その気体の圧力 を測定することができる.

\footnotetext{
* 昭和 61 年11月 12 日 第 27 回真空に関する連合講演会において講演 (12Ap-11)

** 富山大学トリチウム科学センター（富山市五福3190）
}

核融合反応実験で用いる重水素とトリチウムに関して は, 重水素に対する電離真空計の相対感度 ${ }^{3}$, 数種の水 素同位体に対する磁場偏向型質量分析計の相対感度 ${ }^{7}$ は 報告されているが, トリチウムに対する電離真空計の相 対感度は知られていない。四重極質量分析に関しては, Ellefson らの報告があるがその精度に問題がある2).こ のような観点から, 筆者らは 6 種の水素同位体 $\left(\mathrm{H}_{2}\right.$, $\mathrm{HD}, \mathrm{D}_{2}, \mathrm{HT}, \mathrm{DT}, \mathrm{T}_{2}$ ) に対する $\mathrm{B}-\mathrm{A}$ 型電離真空計及び 四重極質分析計の相対感度を測定した。

\section{2. 実験}

\section{1 装 置}

用いた装置の概略を Fig. 1 に示した。この装置の排 気系はスパッタイオンポンプ及び水銀拡散ポンプよりな り, 到達真空度は $2 \times 10^{-6} \mathrm{~Pa}$ 以下である.

$\mathrm{B}-\mathrm{A}$ 型電離真空計（以下 $\mathrm{B}-\mathrm{A}$ と略記）としてはアネ ルバ社製 UGS-1A 及び UGD-1S（以下各々 B-A1及び $\mathrm{B}-\mathrm{A} 2$ と略記）の 2 種類の測定球を用いた。 これらの B$\mathrm{A}$ の作動条件はグリッド電位 $+180 \mathrm{~V}$, フィラメント電



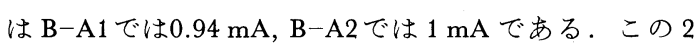
つの測定球の主な相違はガス出し法にある. 即ち B-A1 は電子衝撃型, B-A2はグリッド通電型である.

四重極質量分析計（以下 QMS と略記）としては日本 真空技術社製 MSQ-150 A を用いた。このQMSのイオ ン源はNier型である.な和作条件がエミッション電 


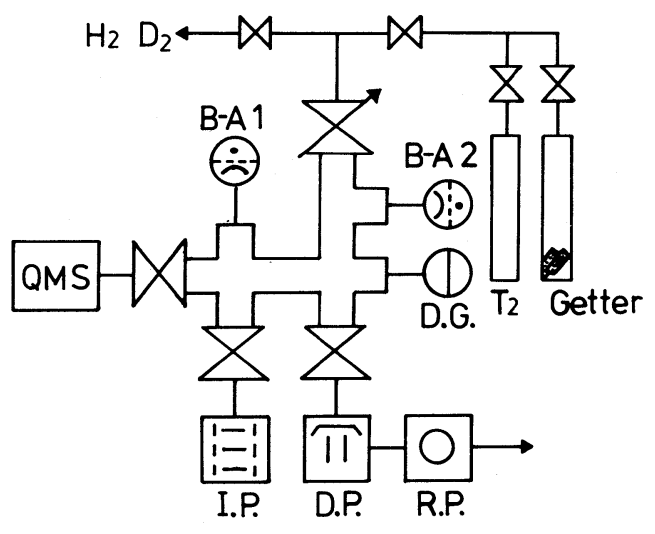

Fig. 1 Schematic diagram of the experimental apparatus: QMS: Quadrupole mass spectrometer, BA: Bayard-Alpert gauge, DG: Diaphragm gauge, IP: Sputter ion pump, DP: Mercury diffusion pump, RP: Oil-sealed rotary pump.

流0.5 mA, 電離電圧70 V, イオン加速電圧 $8 \mathrm{~V}$ の時の 分解能は10\%ピーク高さに拈いて, $\mathrm{M} / \mathrm{e}=2$ で $\Delta \mathrm{M}=0.60, \mathrm{M} / \mathrm{e}=3 \sim 6$ で $\Delta \mathrm{M}=0.61$ であった． また検 出器にはトリチウムの污染の影響がきわめて大きい二次 電子増倍管 $(\mathrm{Cu}-\mathrm{Be})$ は使用せず8), 比較的影響の小さ いファラディカップを用いた.

比較校正用に用いた隔膜真空計は MKS 社製315型で その測定可能圧力範囲は1.33 $1.33 \times 10^{-3} \mathrm{~Pa}$ である.

\section{2 試料気体}

$\mathrm{H}_{2}, \mathrm{D}_{2}$ は日本酸素社製で, 各々の純度は $99.999 \%$ 及 び99\%以上とされている。これらの気体は使用する際に 液体窒素トラップを用いて凝縮性不純物を除去した，又

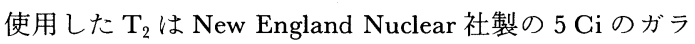
スアンプル入りのものである。この $\mathrm{T}_{2}$ 気体の QMS に よる分析結果を Fig. 2(A)に示した. 図からわかるよう に, 市販の $\mathrm{T}_{2}$ 気体中には ${ }^{3} \mathrm{He}$, トリチウム化メタン $\left(\mathrm{CT}_{4}, \mathrm{etc}\right)$ 及びトリチウム水蒸気 (HTO, etc) 等の不 純物が多量に含まれている，そこで $\mathrm{Zr}-\mathrm{V}-\mathrm{Fe}$ ゲッター に，この気体を一担回収し残留ガスを排気して精製を行 った9). Fig. 2(B)はその後 $\mathrm{Zr}-\mathrm{V}-\mathrm{Fe}$ ゲッターを加熱し て再放出させた気体の質量スペクトルである. 図からわ かるよらに ${ }^{3} \mathrm{He}$ 及び $\mathrm{CT}_{4}$ などの不純物を完全に除去す ることができた。

\section{3 測定方法}

\subsubsection{QMS の校正}

(1) 高純度気体 $\left(\mathrm{H}_{2}, \mathrm{D}_{2}\right)$

$\mathrm{H}_{2}$ 及び $\mathrm{D}_{2}$ の場合には容易に高純度気体を得ること ができる，従って QMS の感度は次式より求められる.

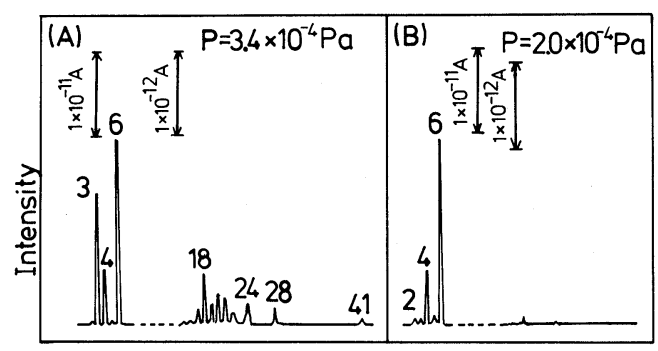

Fig. 2 Mass spectra of as-received tritum gas in a glass ampule (A) and tritium gas purified with use of $\mathrm{Zr}-\mathrm{V}-\mathrm{Fe}$ getter, (B).

$$
\mathrm{S}_{\mathrm{M}}^{\mathrm{X}}=\left(\mathrm{I}_{\mathrm{M}}^{\mathrm{x}} / \mathrm{I}_{\mathrm{M}}^{\mathrm{e}}\right) / \mathrm{P}^{\mathrm{X}}
$$

ここで $\mathrm{S}_{\mathrm{M}}^{\mathrm{X}}$ は成分 $\mathrm{X}$ に対する QMS の感度, $\mathrm{I}_{\mathrm{M}}^{\mathrm{X}}$ 及び $\mathrm{I}_{\mathrm{M}}^{\mathrm{e}}$ はそれぞれ成分 $\mathrm{X}$ のイオン電流及びェミッション電流


隔膜真空計で測定した.

(2) 混合気体

(i) $\mathrm{HD}$

HD は平衡化反応により生成されるため, 通常は純粋 気体の状態では得られないが， $\mathrm{H}_{2}$ と $\mathrm{D}_{2}$ を適当に混合 した気体を用いることにより HDに対する感度を求め ることができる．即ち，この混合気体中の HDの分圧 を $\mathrm{P}^{\mathrm{HD}}$, 隔膜真空計で測定した全圧を $\mathrm{P}_{\text {total }}$ とすれば, $\mathrm{P}^{\mathrm{HD}}$ は次式で示される.

$$
\begin{aligned}
\mathrm{P} & =\mathrm{P}_{\text {total }}-\left(\mathrm{P}^{\mathrm{H}_{2}}+\mathrm{P}^{\mathrm{D}_{2}}\right) \\
& =\mathrm{P}_{\text {total }}-\left[\left(\mathrm{I}_{\mathrm{M}}^{\mathrm{H}_{2}} / \mathrm{S}_{\mathrm{M}}^{\mathrm{H}_{2}}\right)+\left(\mathrm{I}_{\mathrm{M}}^{\mathrm{D}_{2}} / \mathrm{S}_{\mathrm{M}}^{\mathrm{D}_{2}}\right)\right] / \mathrm{I}_{\mathrm{M}}^{\mathrm{e}}
\end{aligned}
$$

$\mathrm{S}_{\mathrm{M}}^{\mathrm{H}_{2}}$ 及び $\mathrm{S}_{\mathrm{M}}^{\mathrm{D}_{2}}$ は各々既に求められているので, 上式より $\mathrm{P}^{\mathrm{HB}}$ が得られ(1)式より $\mathrm{S}_{\mathrm{M}}^{\mathrm{HD}}$ が求められる.

(ii) $\mathrm{HT}, \mathrm{DT}$ 及び $\mathrm{T}_{2}$

Fig. 2(B)に示したよらに本研究においては高純度の $\mathrm{T}_{2}$ を得ることが出来なかったが，この場合にも $\mathrm{H}_{2}$ と $\mathrm{T}_{2}$ 及び $\mathrm{D}_{2}$ と $\mathrm{T}_{2}$ を適当に混合した気体を用いることに より $\mathrm{HT}, \mathrm{DT}$ 及び $\mathrm{T}_{2}$ に対する感度を求めることができ る. 但し, $\mathrm{T}_{2}$ の感度が単独に求められないこと及びこ れらの混合気体中には無視できない量の目的成分以外の 水素同位体成分が微量ではあるが含まれることから以下 のような繰り返し計算法を用いた。

まず $\mathrm{T}_{2}$ と $\mathrm{H}_{2}$ の混合により Fig. 3(A) に示したような $\mathrm{P}_{\mathrm{H}_{2}}>\mathrm{P}_{\mathrm{HT}} \gg \mathrm{P}_{\mathrm{T}_{2}}$ の成分比の混合気体を調整した。 この場 合には HT の分圧 $\mathrm{PHT}^{\mathrm{HT}}$ は次式で示される.

$$
\mathrm{P}^{\mathrm{HT}}=\mathrm{P}_{\text {total }}-\left(\mathrm{P}^{\mathrm{H}_{2}}+\mathrm{P}^{\mathrm{HD}}+\mathrm{P}^{\mathrm{DT}}+\mathrm{P}^{\mathrm{T}_{2}}\right)
$$

第 1 近似として微量成分 $\mathrm{P}^{\mathrm{DT}}$ 及び $\mathrm{P}^{\mathrm{T}_{2}}$ を無視すると第 1 近似としての $\mathrm{HT}$ の分圧 $\mathrm{P}^{\mathrm{HT}(1)}$ は次式で示される。

$$
\begin{aligned}
\mathrm{P}^{\mathrm{HT}(1)} & =\mathrm{P}_{\text {total }}-\left(\mathrm{P}^{\mathrm{H}_{2}}+\mathrm{P}^{\mathrm{HD}}\right) \\
& =\mathrm{P}_{\text {total }}-\left[\left(\mathrm{I}_{\mathrm{M}}^{\mathrm{H}_{2}} / \mathrm{S}_{\mathrm{M}}^{\mathrm{H}_{2}}\right)+\left(\mathrm{I}_{\mathrm{M}}^{\mathrm{HD}} / \mathrm{S}_{\mathrm{M}}^{\mathrm{HD}}\right)\right] / \mathrm{I}_{\mathrm{M}}^{\mathrm{e}}
\end{aligned}
$$


(A)

(B)

(C)
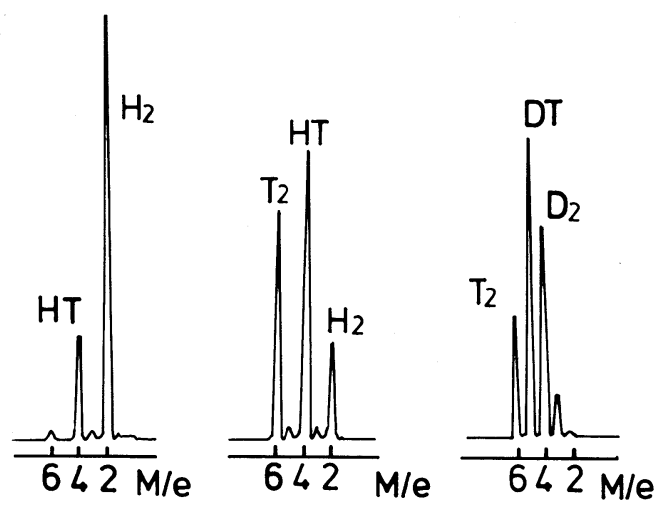

Fig. 3 Example of the mass spectra of gas mixtures used for calibration: (A) and (B) $\mathrm{H}_{2}-\mathrm{T}_{2}$ mixtures, (C) $\mathrm{D}_{2}-\mathrm{T}_{2}$ mixture.

$\mathrm{S}_{\mathrm{M}}^{\mathrm{H}_{2}}$ 及び $\mathrm{S}_{\mathrm{M}}^{\mathrm{HD}}$ は既に求められているので $\mathrm{P}^{\mathrm{HT}(1)}$ が求めら れ，これを(1)式に代入して第 1 近似の HT の感度 $\mathrm{S}_{\mathrm{M}}^{\mathrm{HT}(1)}$ が得られる.

次に Fig. 3(B) 亿示すよらな (A) とは異なる成分比の $\mathrm{H}_{2}$ と $\mathrm{T}_{2}$ の混合気体の全圧と質量スペクトルを測定す る.この場合には, $\mathrm{T}_{2}$ の分圧 $\mathrm{P}^{\mathrm{T}_{2}}$ は次式で示される.

$$
\mathrm{P}^{\mathrm{T}_{2}}=\mathrm{P}_{\text {total }}-\left(\mathrm{P}^{\mathrm{H}_{2}}+\mathrm{P}^{\mathrm{HD}}+\mathrm{P}^{\mathrm{HT}}+\mathrm{P}^{\mathrm{DT}}\right)
$$

HT の場合と同様に微量成分を無視すると, 第 1 近似と しての $\mathrm{T}_{2}$ の分圧 $\mathrm{P}^{\mathrm{T}_{2}(1)}$ は次式で示される.

$$
\begin{aligned}
\mathrm{P}^{\mathrm{T}_{2}(1)}= & \mathrm{P}_{\text {total }}-\left(\mathrm{P}^{\mathrm{H}_{2}}+\mathrm{P}^{\mathrm{HD}}+\mathrm{P}^{\mathrm{HT}}\right) \\
= & \mathrm{P}_{\text {total }}-\left[\left(\mathrm{I}_{\mathrm{M}}^{\mathrm{H}_{2}} / \mathrm{S}_{\mathrm{M}}^{\mathrm{H}_{2}}\right)+\left(\mathrm{I}_{\mathrm{M}}^{\mathrm{HD}} / \mathrm{S}_{\mathrm{M}}^{\mathrm{HD}}\right)\right. \\
& \left.+\left(\mathrm{I}_{\mathrm{M}}^{\mathrm{HT}} / \mathrm{S}_{\mathrm{M}}^{\mathrm{HT}}\right)\right] / \mathrm{I}_{\mathrm{M}}^{\mathrm{e}}
\end{aligned}
$$

$\mathrm{S}_{\mathrm{M}}^{\mathrm{H}_{2}}$ 及び $\mathrm{S}_{\mathrm{M}}^{\mathrm{HD}}$ は既に求められて括り, 先に得た $\mathrm{S}_{\mathrm{M}}^{\mathrm{HT}(1)}$ 用いれば $\mathrm{P}^{\mathrm{T}_{2}(1)}$ が求められ(1)式により第 1 近似の $\mathrm{T}_{2}$ の 感度 $\mathrm{S}_{\mathrm{M}}^{\mathrm{T}_{2}(1)}$ が得られる.

さらにFig. 3(C) に示すよらな $\mathrm{D}_{2}$ と $\mathrm{T}_{2}$ の混合気体の 場合には DT の分圧 $\mathrm{P}^{\mathrm{DT}}$ は次式で示される。

$$
\begin{aligned}
\mathrm{P}^{\mathrm{DT}}= & \mathrm{P}_{\text {total }}-\left(\mathrm{P}^{\mathrm{H}_{2}}+\mathrm{P}^{\mathrm{HD}}+\mathrm{P}^{\mathrm{D}_{2}}+\mathrm{P}^{\mathrm{T}_{2}}\right) \\
= & \mathrm{P}_{\text {total }}-\left[\left(\mathrm{I}_{\mathrm{M}}^{\mathrm{H}_{2}} / \mathrm{S}_{\mathrm{M}}^{\mathrm{H}_{2}}\right)+\left(\mathrm{I}_{\mathrm{M}}^{\mathrm{HD}} / \mathrm{S}_{\mathrm{M}}^{\mathrm{HD}}\right)\right. \\
& \left.+\left(\mathrm{I}_{\mathrm{M}}^{\mathrm{D}_{2}} / \mathrm{S}_{\mathrm{M}}^{\mathrm{D}_{2}}\right)+\left(\mathrm{I}_{\mathrm{M}}^{\mathrm{T}_{2}} / \mathrm{S}_{\mathrm{M}}^{\mathrm{T}_{2}}\right)\right] / \mathrm{I}_{\mathrm{M}}^{\mathrm{e}}
\end{aligned}
$$

ここで先に求めた $\mathrm{S}_{\mathrm{M}}^{\mathrm{T}_{2}(1)}$ を用いると, 第 1 近似の $\mathrm{P}^{\mathrm{DT}(1)}$, 及び感度 $\mathrm{S}_{\mathrm{M}}^{\mathrm{DT}(1)}$ が得られる.

次いで，上で得られた第 1 近似の感度を用いて(4)式 及び(6)式で無視した微量成分を考慮し, 再度 $(\mathrm{A}),(\mathrm{B})$ 及び $(\mathrm{C})$ の質量スペクトルを解析する。即ち, $\mathrm{S}_{\mathrm{M}}^{\mathrm{HT}(1)}$, $\mathrm{S}_{\mathrm{M}}^{\mathrm{T}_{2}(1)}$ 及び $\mathrm{S}_{\mathrm{M}}^{\mathrm{DT}(1)}$ を(3) 式に代入すると以下第 2 近似の $\mathrm{HT}$ の圧力 $\mathrm{P}^{\mathrm{HT}(2)}$ が求められ,

$$
\begin{aligned}
\mathrm{P}^{\mathrm{HT}(2)}= & \mathrm{P}_{\text {total }}-\left[\left(\mathrm{I}_{\mathrm{M}}^{\mathrm{H} 2} / \mathrm{S}_{\mathrm{M}}^{\mathrm{H}}\right)+\left(\mathrm{I}_{\mathrm{M}}^{\mathrm{HD}} / \mathrm{S}_{\mathrm{M}}^{\mathrm{HD}}\right)\right. \\
& \left.+\left(\mathrm{I}_{\mathrm{M}}^{\mathrm{DT}} / \mathrm{S}_{\mathrm{M}}^{\mathrm{DT}(1)}\right)+\left(\mathrm{I}_{\mathrm{M}}^{\mathrm{T}_{2}} / \mathrm{S}_{\mathrm{M}}^{\mathrm{T}_{2}(1)}\right)\right] / \mathrm{I}_{\mathrm{M}}^{\mathrm{e}}
\end{aligned}
$$

第 2 近似の $\mathrm{HT}$ の感度 $\mathrm{S}_{\mathrm{M}}^{\mathrm{HT}(2)}$ が得られる。 また, $\mathrm{S}_{\mathrm{M}}^{\mathrm{HT}(2)}$ 及び $\mathrm{S}_{\mathrm{M}}^{\mathrm{DT}(1)}$ を(5) 式に代入寸れば，以下の上うに第 2 近 似の $\mathrm{T}_{2}$ の圧力 $\mathrm{P}^{\mathrm{T}_{2}(2)}$ 求められ,

$$
\begin{aligned}
\mathrm{P}^{\mathrm{T}_{2}(2)}= & \mathrm{P}_{\text {total }}-\left[\left(\mathrm{I}_{\mathrm{M}}^{\mathrm{H}_{2}} / \mathrm{S}_{\mathrm{M}}^{\mathrm{H}_{2}}\right)+\left(\mathrm{I}_{\mathrm{M}}^{\mathrm{HD}} / \mathrm{S}_{\mathrm{M}}^{\mathrm{HD}}\right)\right. \\
& \left.+\left(\mathrm{I}_{\mathrm{M}}^{\mathrm{HT}} / \mathrm{S}_{\mathrm{M}}^{\mathrm{HT}(2)}\right)+\left(\mathrm{I}_{\mathrm{M}}^{\mathrm{DT}} / \mathrm{S}_{\mathrm{M}}^{\mathrm{DT}(1)}\right)\right] / \mathrm{I}_{\mathrm{M}}^{\mathrm{e}}
\end{aligned}
$$

これより第 2 近似の $\mathrm{T}_{2}$ の感度 $\mathrm{S}_{\mathrm{M}}^{\mathrm{T}_{2}(2)}$ が得られる. 同様 に $\mathrm{S}_{\mathrm{M}}^{\mathrm{HT}(2)}$ 及び $\mathrm{S}_{\mathrm{M}}^{\mathrm{T}_{\mathrm{T}}(2)}$ を(7) 式に用いることにより第 2 近 似の DT の感度 $\mathrm{S}_{\mathrm{M}}^{\mathrm{DT}(2)}$ が求められる。以上の近似計算 を繰り返し行うことにより，より正確な $\mathrm{HT}, \mathrm{T}_{2}$ 及び DT の感度が得られる。

\subsubsection{B-A の校正}

(1) 高純度気体 $\left(\mathrm{H}_{2}, \mathrm{D}_{2}\right)$

高純度気体の B-A における感度はとれぞれ圧力を隔 膜真空計で測定することにより次式から求められる.

$$
\mathrm{S}_{\mathrm{B}}^{\mathrm{X}}=\left(\mathrm{I}_{\mathrm{B}}^{\mathrm{X}} / \mathrm{I}_{\mathrm{B}}^{\mathrm{e}}\right) / \mathrm{P}^{\mathrm{X}}
$$

ここで, $\mathrm{S}_{\mathrm{B}}^{\mathrm{X}}$ 及び $\mathrm{I}_{\mathrm{B}}^{\mathrm{X}}$ は成分 $\mathrm{X}$ の $\mathrm{B}-\mathrm{A}$ 亿おける感度及び イオン電流， $\mathrm{I}_{\mathrm{B}}^{\mathrm{e}}$ は土ミッション電流である。

(2) 混合気体

B-Aのイオン電流が混合気体の各成分のイオン電流 の和であると仮定し，各成分の分圧を感度校正した QMS で求めると以下の方法により HD, HT, DT 及び $\mathrm{T}_{2}$ の $\mathrm{B}-\mathrm{A}$ における感度が得られる。

(i) $\mathrm{HD}$

$\mathrm{H}_{2}$ と $\mathrm{D}_{2}$ の混合気体中の $\mathrm{HD}$ のイオン電流は次式で 表わされる。

$$
\begin{aligned}
\mathrm{I}_{\mathrm{B}}^{\mathrm{HD}} & =\mathrm{I}_{\mathrm{B}}-\left(\mathrm{I}_{\mathrm{B}}^{\mathrm{H}_{2}}+\mathrm{I}_{\mathrm{B}}^{\mathrm{D}_{2}}\right) \\
& =\mathrm{I}_{\mathrm{B}}-\mathrm{I}_{\mathrm{B}}^{\mathrm{e}}\left(\mathrm{S}_{\mathrm{B}}^{\mathrm{H}_{2}} \mathrm{P}^{\mathrm{H}_{2}}+\mathrm{S}_{\mathrm{B}}^{\mathrm{D}_{2}} \mathrm{P}^{\mathrm{D}_{2}}\right)
\end{aligned}
$$

ここで $\mathrm{H}_{2}$ 及び $\mathrm{D}_{2}$ の分圧は $\mathrm{QMS} よ り$ 得られる。ま た, $\mathrm{H}_{2}$ 及び $\mathrm{D}_{2}$ の感度は既に得られているので上式よ り $\mathrm{I}_{\mathrm{B}}^{\mathrm{HD}}$ を求めることができ, この值を(10)式に代入し, $\mathrm{S}_{\mathrm{B}}^{\mathrm{HD}}$ が得られる。この際 $\mathrm{P}^{\mathrm{HD}}$ は QMS により求める.

(ii) $\mathrm{HT}, \mathrm{DT}$ 及び $\mathrm{T}_{2}$

B-A に打ける HT, DT 及び $\mathrm{T}_{2}$ のイオン電流は $\mathrm{H}_{2}$ と $\mathrm{T}_{2}$ 及び $\mathrm{D}_{2}$ と $\mathrm{T}_{2}$ の混合気体に対して各々次式で示され る.

$$
\begin{aligned}
\mathrm{I}_{B}^{\mathrm{HT}}= & \mathrm{I}_{\mathrm{B}}-\mathrm{I}_{\mathrm{B}}^{\mathrm{e}}\left(\mathrm{S}_{\mathrm{B}}^{\mathrm{H}_{2}} \mathrm{P}^{\mathrm{H}_{2}}+\mathrm{S}_{\mathrm{B}}^{\mathrm{HD}} \mathrm{P}^{\mathrm{HD}}\right. \\
& \left.+\mathrm{S}_{\mathrm{B}}^{\mathrm{DT}} \mathrm{P}^{\mathrm{DT}}+\mathrm{S}_{\mathrm{B}}^{\mathrm{T}_{2}} \mathrm{P}^{\mathrm{T}_{2}}\right) \\
\mathrm{I}_{\mathrm{B}}^{\mathrm{T}_{2}}= & \mathrm{I}_{\mathrm{B}}-\mathrm{I}_{\mathrm{B}}^{\mathrm{e}}\left(\mathrm{S}_{\mathrm{B}}^{\mathrm{H}_{2}} \mathrm{P}^{\mathrm{H}_{2}}+\mathrm{S}_{\mathrm{B}}^{\mathrm{HD}} \mathrm{P}_{\mathrm{B}}^{\mathrm{HD}}+\mathrm{S}_{\mathrm{B}}^{\mathrm{HT}} \mathrm{P}^{\mathrm{HT}}\right. \\
& \left.+\mathrm{S}_{\mathrm{B}}^{\mathrm{DT}} \mathrm{P}^{\mathrm{DT}}\right) \\
\mathrm{I}_{\mathrm{B}}^{\mathrm{DT}}= & \mathrm{I}_{\mathrm{B}}-\mathrm{I}_{\mathrm{B}}^{\mathrm{e}}\left(\mathrm{S}_{\mathrm{B}}^{\mathrm{H}_{2}} \mathrm{P}^{\mathrm{H}_{2}}+\mathrm{S}_{\mathrm{B}}^{\mathrm{HD}} \mathrm{P}^{\mathrm{HD}}\right. \\
& \left.+\mathrm{S}_{\mathrm{B}}^{\mathrm{D}_{2}} \mathrm{P}^{\mathrm{D}_{2}}+\mathrm{S}_{\mathrm{B}}^{\mathrm{T}_{2}} \mathrm{P}^{\mathrm{T}_{2}}\right)
\end{aligned}
$$

これらの式は QMS の感度校正における式(3)，(5)及び (7)の関係と同じである. 従って, QMS の場合と同様 の繰り返し計算法により $\mathrm{HT}, \mathrm{DT}$ 及び $\mathrm{T}_{2}$ に対する $\mathrm{B}-$ A の感度が得られる。

なお本実験での操作条件下では，質量スペクトルにお 


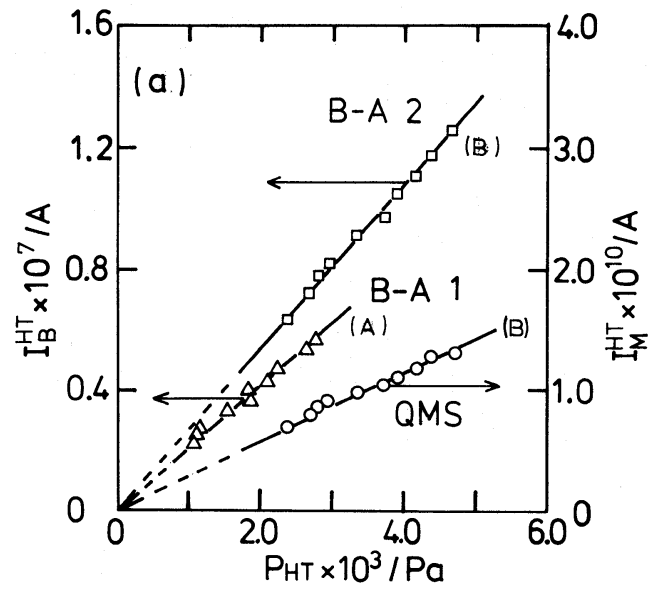

(a)

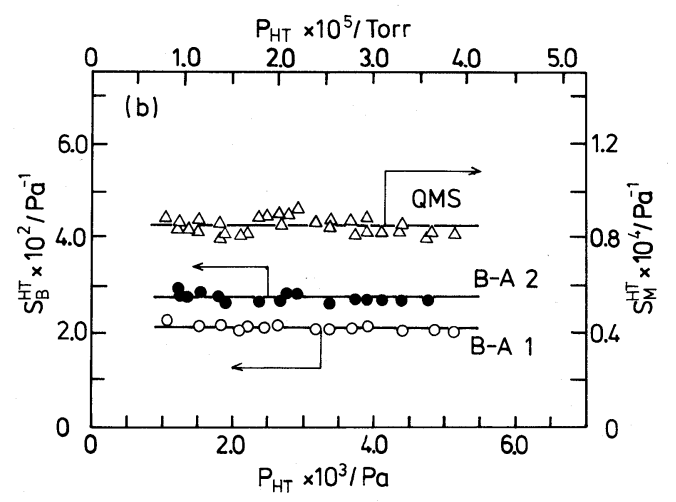

(b)

Fig. 4 Calibration curves of the mass spectrometer and B-A guages for HT: (a) B-A 1 results for the gas mixture shown in Fig. 3 (A), B-A 2 and QMS results for the gas mixture shown in Fig. 3(B): (b) Summary of the calibration results.

ける三原子イオン（例えば, $\mathrm{H}_{3}^{+}, \mathrm{D}_{3}^{+}, \mathrm{T}_{3}^{+}$) のピークは 二原子イオン $\left(\mathrm{H}_{2}^{+}, \mathrm{D}_{2}^{+}, \mathrm{T}_{2}^{+}\right)$のピーク強度の1/1000以 下で, 無視できる. 他方, $\mathrm{D}_{2}$ 測定時の単原子イオン $\left(\mathrm{D}^{+}\right)$のピークは $\mathrm{D}_{2}^{+}$のピーク強度の7/1000以下であ

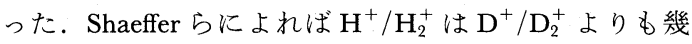
分大きく, $\mathrm{T}^{+} / \mathrm{T}_{2}^{+}$は幾分小さい(10). 従って, 質量スペ クトルヘの単原子イオンの寄与は, 三原子イオンの場合 と同様に無視できる. 即ち, 質量スペクトルの解析の際 には上記のよらに二原子イオンのみを考慮すればよい. B-Aの測定においても同様であると考えられる.

上記の測定において， $\mathrm{B}-\mathrm{A}$ の $\mathrm{H}_{2}$ 及び $\mathrm{D}_{2}$ に対する排 気速度はともに約 $1.0 \mathrm{l} / \mathrm{s}$ であった。 $\mathrm{B}-\mathrm{A}$ 球の枝管のコ ンダクタンスを考慮すると, B-A 球内の圧力は系の圧 カよりも約 $4 \%$ ほど低い，ここでは他の水素同位体分子 に対しても同じ排気速度であるとして，一律に排気作用 の補正を行った。他方，QMS に関してはその排気作用 は小さく，かつコンダクタンスは大きいので，その影響 は無視した. 更に, 隔膜真空計は $46^{\circ} \mathrm{C}$ で操作したので,こ れに対しては熱遷移の補正を行った $\left(\mathrm{P}_{1} / \mathrm{P}_{2}=\sqrt{\mathrm{T}_{1} / \mathrm{T}_{2}}\right)$.

\section{3. 結果と考察}

Fig. 4(a)に一例として $\mathrm{H}_{2}-\mathrm{T}_{2}$ 混合気体の測定で得ら れた $\mathrm{I}_{\mathrm{M}}^{\mathrm{HT}}$ と $\mathrm{I}_{\mathrm{B}}^{\mathrm{HT}}$ を $\mathrm{HT}$ の分圧に対してプロットしたもの を示す．ここでB-A1の結果はFig. 3(A)の組成の混合 気体, B-A2及び QMS の結果はFig. 3(B)の組成の混 合気体で得られたものである。なおこれらの值は横軸の $\mathrm{P}^{\mathrm{HT}}$ b含めて, 全ての同位体分子に対して最終的に得ら れた感度を用いて求めたものである．横軸の圧力範囲が
Table 1 Relative sensitivities of the mass spectrometer for hydrogen isotopes $\left(R_{\mathrm{M}}^{\mathrm{X}}=S_{\mathrm{M}}^{\mathrm{X}} / S_{\mathrm{M}}^{\mathrm{H}_{2}}\right)$.

\begin{tabular}{l|l|c}
\hline \hline Gas & This work & Dibeler et al. \\
\hline $\mathrm{H}_{2}$ & 1.00 & 1.00 \\
$\mathrm{HD}$ & $1.09 \pm 0.06$ & 1.06 \\
$\mathrm{D}_{2}$ & $0.99 \pm 0.03$ & 0.98 \\
$\mathrm{HT}$ & $1.06 \pm 0.06$ & 1.04 \\
$\mathrm{DT}$ & $0.96 \pm 0.04$ & - \\
$\mathrm{T}_{2}$ & $0.88 \pm 0.03$ & 0.89 \\
\hline $\mathrm{N}_{2}$ & $0.67 \pm 0.02$ & - \\
\hline
\end{tabular}

狭いのは，隔膜真空計での測定下限が $1 \times 10^{-3} \mathrm{~Pa}$ であ ること，B-A 及び QMS 出力の直線性が全圧約 $3 \times 10^{-2}$ $\mathrm{Pa}$ 以上で失われること並びに混合気体中の一成分を測 っていること等によるものである．種々の組成の $\mathrm{H}_{2}$ $\mathrm{T}_{2}$ 混合気体で得られた B-A 及び QMS の HT に対する 感度をまとめると Fig. 4(b)のようになる.図のように B-A1及び 2 並びに QMS $の$ HT に対する感度は 1 ～ $5 \times$ $10^{-3} \mathrm{~Pa}$ の範囲内で一定で，それぞれ $\mathrm{S}_{\mathrm{B}}^{\mathrm{HT}}(\mathrm{B}-\mathrm{A} 1)=$ $(2.23 \pm 0.08) \times 10^{-2} / \mathrm{Pa}, \mathrm{S}_{\mathrm{B}}^{\mathrm{HT}}(\mathrm{B}-\mathrm{A} 2)=(2.78 \pm 0.08) \times$ $10^{-2} / \mathrm{Pa}, \mathrm{S}_{\mathrm{M}}^{\mathrm{HT}}=(8.55 \pm 0.45) \times 10^{-5} / \mathrm{Pa}$ と求められた.

Table 1 に 6 種の水素同位体に対する QMS の感度を まとめた。な扢ここでは $\mathrm{H}_{2}$ の感度を 1 とした相対感度 $\left(\mathrm{R}_{\mathrm{M}}^{\mathrm{X}}=\mathrm{S}_{\mathrm{M}}^{\mathrm{X}} / \mathrm{S}_{\mathrm{M}}^{\mathrm{H}_{2}}\right)$ を示した. いづれの水素同位体の場合 も統計誤差は $6 \%$ 以内である。比較のために Dibeler ら の磁場偏向型質量分析計の結果を示した ${ }^{7)}$. 測定原理及 び幾何学的構造が異なるにもかかわらず，両者は極めて 
Table 2 Relative sensitivities of the B-A guages for hydrogen isotopes $\left(R_{\mathrm{M}}^{\mathrm{X}}=S_{\mathrm{M}}^{\mathrm{X}} / S_{\mathrm{M}}^{\mathrm{H}_{2}}\right)$.

\begin{tabular}{l|l|l|l|l}
\hline \hline Gas & \multicolumn{1}{|c|}{ B-A 1 } & \multicolumn{1}{|c|}{ B-A 2 } & Average & $R_{\mathrm{M}} / R_{\mathrm{B}}$ \\
\hline $\mathrm{H}_{2}$ & 1.00 & 1.00 & 1.00 & 1.00 \\
$\mathrm{HD}$ & $1.06 \pm 0.08$ & $1.10 \pm 0.06$ & $1.08 \pm 0.05$ & $1.01 \pm 0.01$ \\
$\mathrm{D}_{2}$ & $0.99 \pm 0.01$ & $0.98 \pm 0.02$ & $0.99 \pm 0.01$ & $1.00 \pm 0.02$ \\
$\mathrm{HT}$ & $1.04 \pm 0.04$ & $1.02 \pm 0.06$ & $1.03 \pm 0.04$ & $1.03 \pm 0.02$ \\
$\mathrm{DT}$ & $0.97 \pm 0.04$ & $0.97 \pm 0.04$ & $0.97 \pm 0.03$ & $0.99 \pm 0.01$ \\
$\mathrm{~T}_{2}$ & $0.95 \pm 0.02$ & $0.95 \pm 0.03$ & $0.95 \pm 0.02$ & $0.92 \pm 0.01$ \\
\hline $\mathrm{N}_{2}$ & $2.50 \pm 0.02$ & $2.13 \pm 0.014$ & $(2.3 \pm 0.2)$ & $(0.29 \pm 0.05)$ \\
\hline
\end{tabular}

良く一致することが知られた.

2 種類の B-A の校正結果を Table 2 に示した。この 表も $\mathrm{H}_{2}$ の感度を 1 とした相対感度 $\left(\mathrm{R}_{\mathrm{B}}^{\mathrm{X}}=\mathrm{S}_{\mathrm{B}}^{\mathrm{X}} / \mathrm{S}_{\mathrm{B}}^{\mathrm{H}_{2}}\right)$ で示 してある，窒素に対する感度は $\mathrm{B}-\mathrm{A} 1$ と 2 では若干異な るが，水素同位体に対しては両者の相対感度は極めて良 く一致した．これらの QMS 及び B-Aの相対感度は, それぞれの出力の直線性の成立する範囲（本実験では全 圧 $3 \times 10^{-2} \mathrm{~Pa}$ 以下）で有効であると考兄られる。なお 水素同位体と比較して, 窒素に対する相対感度が $\mathrm{B}-\mathrm{A} 1$ と 2 で異なる理由は明らかではないが，両者の電極構造 の相違が窒素イオンの収集効率に影響しているためと考 えられる11).

以上の結果から B-Aについては $\mathrm{H}_{2}$ の感度を得るこ とにより単一成分であれば他の全ての水素同位体の圧力 を測定できる。しかし，QMSでは分解能などの動作条 件や装置の設計条件により相対感度が異なる可能性があ る. Fig. 5 は分解能を変えて $\mathrm{H}_{2}$ 及び $\mathrm{HD}$ の感度を測定 した結果である。図のよ5に $\mathrm{HD}, \mathrm{H}_{2}$ 及び $\mathrm{N}_{2}$ に対する 相対感度は測定誤差範囲内で一定であることが知られ た，即ち，相対感度への分解能の影響はなく，同種の装 置であれば本実験で得られた結果が有効であると結論さ れる。なお， $\mathrm{D}_{2}$ での結果は $\mathrm{H}_{2}$ の結果と実験誤差の範 囲内で一致するので本図からは割愛した。

Table 2 に示したよらに, $\mathrm{H}_{2}, \mathrm{D}_{2}, \mathrm{HT}$ 及びDTに対 する B-Aの相対感度は誤差範囲内で一致し, Nakaoの 報告にあるよらな $\mathrm{H}_{2}$ と $\mathrm{D}_{2}$ の間の大きな相対感度の相 違 $\left(\mathrm{S}_{\mathrm{B}}^{\mathrm{D}_{2}} / \mathrm{S}_{\mathrm{B}}^{\mathrm{H}_{2}}=0.83 \sim 0.91\right)$ は認められなかった3). 他方, $\mathrm{HT}$ と $\mathrm{T}_{2}$ に関しては一明らかに $\mathrm{S}_{\mathrm{B}}^{\mathrm{HT}}$ は $\mathrm{S}_{\mathrm{B}}^{\mathrm{H}_{2}}$ よりも大き く, 他力 $\mathrm{S}_{\mathrm{B}}^{\mathrm{T}}$ 㲺小さいこの結果は, 従来知られている 感度とイオン化断面積との密接な関係を考慮すると, イ オン化断面積の差によるものと考えられる.この説明は QMSの結果からも支持される。即ち，Table 1 に見ら れるように, QMS においても $\mathrm{S}_{\mathrm{M}}^{\mathrm{HD}}$ は $\mathrm{S}_{\mathrm{M}}^{\mathrm{H}_{2}}$ よりも大きく, $\mathrm{S}_{\mathrm{M}}^{\mathrm{T}_{2}}$ は小さい点で $\mathrm{B}-\mathrm{A}$ で得られた結果と一致している.

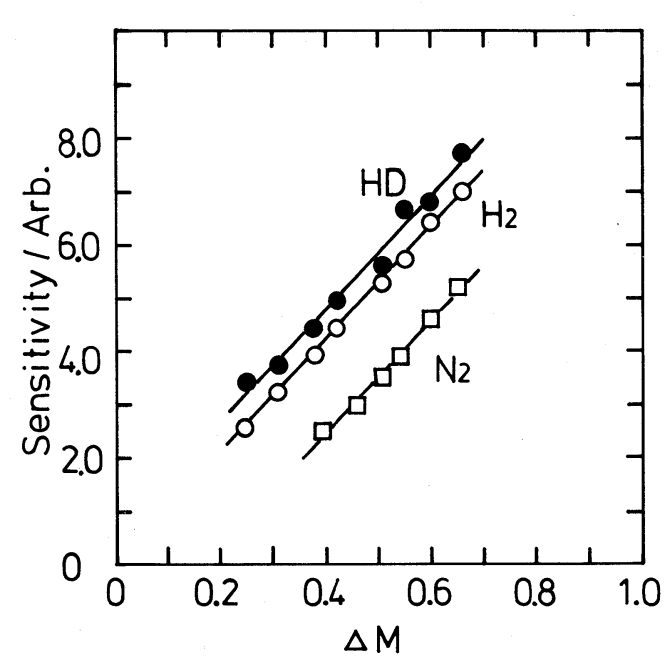

Fig. 5 Changes in the sensitivities of the QMS with resolution.

従って, B-A 球内に拉将る複雑なイオン化過程及びイ オン収集過程にもかかわらず， $\mathrm{S}_{\mathrm{B}}^{\mathrm{HD}}$ 及び $\mathrm{S}_{\mathrm{B}}^{\mathrm{T}_{2}}$ と $\mathrm{S}_{\mathrm{B}}^{\mathrm{H}_{2}}$ との 相違はイオン化断面積の相違を反映しているものと結論 できる。

ここで, 水素同位体に対する B-A と QMS との相対 感度を比較すると（ $\left.\mathrm{R}_{\mathrm{M}}^{\mathrm{X}} / \mathrm{R}_{\mathrm{B}}^{\mathrm{X}}\right), \mathrm{H}_{2} \sim \mathrm{DT}$ までは実験誤差 内で 1 に等しく，他方 $\mathrm{T}_{2}$ の場合には明らかに 1 よりも 小さい。この結果, 即ち $\mathrm{T}_{2}$ に対する QMS の低い相対 感度はイオン化過程以外の影響が現われたためであると 解釈できる，Dibelerらは，トリチウムに対する低い感 度は主として質量差別によるものとしたが7), 本研究で $\mathrm{R}_{\mathrm{M}}^{\mathrm{T}_{2}} / \mathrm{R}_{\mathrm{B}}^{\mathrm{T}_{2}}<1$ となった理由も, 質量差別即ち $\mathrm{T}_{2}^{+}$イオン の透過率の低下によるものと考えられる. 窒素について の結果 $\left(\mathrm{R}_{\mathrm{M}}^{\mathrm{T}_{2}} / \mathrm{R}_{\mathrm{B}}^{\mathrm{T}_{2}} \simeq 0.3\right)$ は上記の説明を裏付けている. 従って, $\mathrm{T}_{2}$ に対する $\mathrm{QMS}$ の低い相対感度 $\left(\mathrm{R}_{\mathrm{M}}^{\mathrm{T}_{2}}=\right.$ 0.88）に関しては, その一部はイオン化断面積の相違 に，また一部は質量差別に帰せられる。なお，上記の QMS での結果はイオン検出器にファラディカップを用 いていることに注意する必要がある. 二次電子増倍管を 用いた場合には，より著しい質量差別効果があり，更に その操作条件により複雑な影響が現われてくる.

\section{4. よ め}

6 種の水素同位体に対する四重極質量分析計及び B$\mathrm{A}$ 型電離真空計の感度を測定した。 その結果以下の知 見が得られた。

(1) B-A の感度は $\mathrm{H}_{2}, \mathrm{D}_{2}, \mathrm{HT}$ 及び DTでは実験䛊 差範囲内で一致するが， $\mathrm{HD}$ に対する感度は $\mathrm{H}_{2}$ の 
それよりも約 $10 \%$ 大きく， $\mathrm{T}_{2}$ に対する感度は約 5 \%ほど小さい。この相違はイオン化断面積によるも のである。

(2) 同様な傾向は QMS についても認められた。 即ち, $\mathrm{HD}$ に対する感度は $\mathrm{H}_{2}$ よりも約 $10 \%$ 大きく， $\mathrm{T}_{2}$ に 対する感度は約 $10 \%$ 小さい，後者の低い相対感度は 一部はイオン化断面積の相違によるものであり，ま た一部は質量差別に基づくものである.

(3) QMS での相対感度は分解能が数倍変っても影響 を受けない。

\section{〔文献〕}

1) H. F. Dylla: J. Vac. Sci. Technol., 20 (1982) 119.

2) R. E. Ellefson, E. Moddeman and H. F. Dylla: J. Vac. Sci. Technol., 18 (1981) 1062.

3) F. Nakao: Vacuum, 25 (1975) 201, 431.

4) K. Nakayama and H. Hojyo: Jpn. J. Appl. Phys.
Suppl. 2, Pt. 1, (1974) 113.

5) R. Holando: J. Vac. Sci. Technol., 10 (1973) 113.

6) T. A. Flaim and P. D. Owndy: J. Vac. Sci. Technol., 8 (1971) 661.

7) V. H. Dibeler, F. L. Mohler, E. J. Wells, Jr. and R. M. Reese: J. Res. Natl. Bur. Standers, 45 (1950) 288 : Phys. Rev., 79 (1950) 223.

8) K. Ichimura, N. Inoue, K. Ashida, M. Matsuyama, H. Miyake and K. Watanabe: Radioisotopes, 34 (1985) 83.

9) K. Ichimura, N. Inoue, K. Watanabe and T. Takeuchi: J. Vac. Sci. Technol., A2 (1984) 1341, A3 (1985) 346: Ann. Rept. Tritium Res. Center Toyama Univ., 2 (1982) 69, 3 (1983) 33, 4 (1984) 37.

10) O. A. Schaeffer and J. M. Hastings: J. Chem. Phys., 18 (1950) 1048.

11) P. A. Redhead, J. P. Hobson and E. V. Konersen 著, 富永五郎, 辻 泰訳 : 超高真空の物理（岩波書 店, 1977) p. 276. 